\title{
Assessment and analysis of ecosystem services value along the Yangtze River under the background of the Yangtze River protection strategy
}

\author{
ZHENG Liang ${ }^{1}$, LIU Hai ${ }^{1,4}$, HUANG Yuefei ${ }^{1}$, YIN Shoujing ${ }^{2},{ }^{*}$ JIN Gui \\ 1. Faculty of Resources and Environmental Science, Hubei University, Wuhan 430062, China; \\ 2. Ministry of Environmental Protection, Satellite Environment Center, Beijing 100094, China; \\ 3. College of Urban and Environment Science, Central China Normal University, Wuhan 430079, China \\ 4. School of Remote Sensing and Information, Wuhan University, Wuhan 430062, China
}

\begin{abstract}
The Yangtze River is the third largest river in the world and the longest and largest river in China. China has adopted a national strategy to protect the Yangtze River. A better understanding of the ecosystem services value along the Yangtze River would provide support for the Yangtze River protection strategy. Using Costanza's method to estimate the ecosystem services value, the value of 10 ecosystem services was estimated within $1 \mathrm{~km}$ and $2 \mathrm{~km}$ from the Yangtze River in 2017. These 10 services were derived from the four established groupings of provisioning, regulating, supporting, and cultural services. This study compared and analyzed the changes in the ecosystem services value in the upper, middle, and lower reaches of the river, and in provinces, cities, and villages along the Yangtze River. The total ecosystem services value within $1 \mathrm{~km}$ and $2 \mathrm{~km}$ from the river was 37.208 and 43.769 billion yuan, respectively. Within $1 \mathrm{~km}$, the ecosystem services value in the middle reaches was 12.93 billion yuan, while the next highest value was in the upper reaches at 12.45 billion yuan, and the downstream area had the smallest value of 11.855 billion yuan. Within $2 \mathrm{~km}$, the value of upstream ecosystem services was the highest at 16.31 billion yuan, while the second highest value was in the middle reaches at 14.376 billion yuan, and the smallest value was in the downstream area at 13.083 billion yuan. In the Yangtze River Basin, regulating services played a leading role, accounting for $81.6 \%$ and $78.9 \%$ of the ecosystem services value within $1 \mathrm{~km}$ and $2 \mathrm{~km}$ from the river, respectively. Among the 10 ecosystem services, hydrological regulation was the most important, while the value of raw material production made the smallest contribution. Among the provinces and cities along the Yangtze River, the highest ecosystem services value was in Hubei Province, while the lowest values were in Shanghai and the Qinghai-Tibet Plateau. If villages within $1 \mathrm{~km}$ and $2 \mathrm{~km}$ from the
\end{abstract}

Received: 2019-04-25 Accepted: 2019-12-29

Foundation: National Key Research and Development Program of China, No.2018YFC1506500, National Natural Science Foundation of China, No.71974070, No.41501593, No.41971402; Social Sciences Foundation of the Ministry of Education of China, No.19YJCZH068; Open Research Fund of Hubei Provincial Key Laboratory of Regional Development and Environmental Response (2018B(003))

Author: Zheng Liang (1994-), Master Candidate, specialized in integrated watershed management.

E-mail: 1241580102@qq.com

*Corresponding author: Jin Gui (1986-), PhD and Associate Professor, specialized in land resources evaluation and national land management. E-mail: jingui@igsnrr.ac.cn 
river were to be relocated, the total regional ecological value would increase by 527 and 975 million yuan, respectively.

Keywords: Yangtze River Basin; 1 km along the Yangtze River; 2 km along the Yangtze River; value assessment method; ecosystem services

\section{Introduction}

Ecosystem services are benefits that are directly or indirectly derived through the structure, processes, and functions of ecosystems. The concept was first proposed by Wilson (1970), and then several other researchers further developed the study of ecosystem services (e.g., Costanza et al., 1997; Daily et al., 2009). Ecosystem services are divided into provisioning, regulating, supporting, and cultural services, and include economic, ecological, and social values related to the ecosystem. The concept provides a specific monetization of the quality of ecosystem services and is effective in resource management. A rational allocation of ecological resources can provide a reference for environmental policy and ecological management (Bolliger et al., 2011; MEA, 2005). Ecosystem service value assessments have been widely applied in various ecosystems (Berta et al., 2014; Raudsepp-Hearne et al., 2010; Nieto-Romero et al., 2010), especially in the assessment of conservation effectiveness in nature reserves (mainly national parks). These studies have covered global, regional, and different scales, such as entire states and individual protected areas, and have also spanned representative ecosystems, such as forests, wetlands, grasslands, and deserts, and major protected objects, such as wildlife.

In recent years, many studies have been conducted on the evaluation of ecosystem services worldwide. With the introduction of remote sensing and other spatial information data, the field of ecosystem services assessment expanded, and ecosystem services value assessments were developed. Currently, the main evaluation methods include the material quality evaluation (Huang et al., 2013), energy evaluation method (Fu et al., 2017), and value assessment method (Li et al., 2019). The material quality assessment method can estimate the ecosystem services value on a spatial scale. This method has obvious advantages in research at regional and landscape scales and can be used to determine the overall pattern of ecosystem services based on the unit of the calculated dimension. For various reasons, this method has certain limitations in its application (Huang et al., 2013). An energy assessment is mainly used to convert various forms of energy into a unified unit, which can solve the problem of double counting in the evaluation of ecosystem services, but this method is very sensitive to data changes and cannot provide an economic value for all ecosystems (Wang and He, 2013; Jin et al., 2019). The core of a value assessment is the market value theory in ecological economics. It mainly evaluates ecosystem services from the perspective of monetary value. The value assessment method is more universal, and the data demands are small. It is applicable to many regions and various ecosystem types. Studies of ecosystem services at different scales and the ecosystem services value can be modified according to the actual situation of the study area to better reflect the spatial heterogeneity of ecosystem services value (Fu, 2013; Jin et al., 2018). In 1997, Costanza used this method to estimate the ecosystem services value in various ecosystems around the world, and the approach was then widely used to assess the ecosystem services value at global and regional scales. Xie et al. (2008) revised the ecosystem services value classification and the tables of equivalent value 
value per unit area based on knowledge from more than 700 ecological experts. The ecosystem service classification was changed from the original Costanza method and 17 other types and was revised to include four first-level categories. With nine secondary categories, studies of the value of China's ecosystem services have entered a new stage (Chen et al., 2019). Therefore, in this study, we estimate the ecosystem service value of the Yangtze River Basin based on the value assessment method and referring to the revised ecosystem service value classification system by Xie et al. (2008).

Land use patterns directly affect the types of services and supplies provided by ecosystems, with changes in land cover driving changes in ecosystem services (Fisher and Turner, 2008; Kreuter et al., 2001). Exploring the impact of land use changes on ecosystem services can be used as a means to link the ecological processes with human activities, such as ecological processes and urbanization. The effect of ecological restoration plays an important feedback role in the evaluation and prediction of the spatial pattern of regional ecosystem services (Wiens, 2009; Priess et al., 2007). Many researchers have used land use to introduce correction coefficients when building an ecosystem service system. This method has constantly improved the quantitative framework of ecosystem services value (Ouyang et al., 1999; Xie et al., 2015).

China's Yangtze River Basin has always occupied an extremely important position in China's social and economic development, with vast natural resources, a diverse economic culture, and important geographical advantages. There have been great achievements in the governance and development of the Yangtze River region in recent decades, but at the same time the ecological environment of the river basin has undergone adverse changes that cannot be ignored. In 2018, the pollution of main tributaries in the Yangtze River Basin was relatively serious, with $14.2 \%$ of the tributaries exceeding class III, and $2 \%$ of the tributaries were inferior to class V (Yang et al., 2019). In 2017, the proportion of total phosphorus in the national control sections of Yunnan, Guizhou and Sichuan provinces exceeded class III was $26.9 \%, 20.8 \%$ and $18.7 \%$, respectively. In Hunan, Chongqing and Yunnan, the proportion of total phosphorus over class III in the national control section was $81.0 \%, 75.0 \%$ and $72.7 \%$ respectively. In Tuojiang, Wujiang and Minjiang river basins, $64.3 \%, 40.7 \%$ and $27.4 \%$ of the total phosphorus in the national control sections exceeded class III, respectively. The total phosphorus has become the primary one over standard pollution factor in the Yangtze River (Xu et al., 2015). These changes have already started to affect the economic development of some cities in the Yangtze River Economic Belt. On January 5, 2016, General Secretary Xi Jinping emphasized at a symposium to promote the development of the Yangtze River Economic Belt that it is necessary to protect existing large-scale development and to not engage in further large-scale development. After the 'Conservation of the Yangtze River' was proposed as a concept, the protection of the ecological environment of the Yangtze River was raised to the national strategic level.

Existing studies of ecosystem services in the Yangtze River Basin include Liu et al. (2017), who studied changes based on land use types to explore the changes and characteristics of the ecosystem services value in the middle reaches of the Yangtze River in 2000-2010. Chen et al. (2019) used 1995 and 2005 land use/cover change data in an ecosystem services value measurement model for these years and 2015. They measured the spatial and temporal differentiation characteristics of the county ecosystem services value in the middle reaches 
of the Yangtze River and responded to the land use changes in the middle reaches of the Yangtze River. Their study also investigated spatial sensitivity. Yang et al. (2018) considered the land use changes in the middle reaches of the Yangtze River in 1990-2014 and used Costanza's model to estimate the ecosystem services value and analyze their temporal and spatial variations. Cheng et al. (2017) used the remote sensing results of land use status in 2000, 2005, and 2010 to analyze the changes in land use patterns, processes, regional characteristics, and ecosystem service functions in the Yangtze River Basin. There have been many studies of the middle reaches of the Yangtze River, many of which have focused on the characteristics of changes in regional ecosystem services values. A few studies have investigated the contribution of environmental protection measures in the Yangtze River Basin to the value of watershed ecosystem services. There are different eco-environmental problems in the upper, middle and lower reaches of the Yangtze River Basin. The comprehensive assessment of the value of the basin ecosystem and the analysis of the value of the ecosystem in different administrative regions are conducive to the cooperative attitude among the administrative regions to cope with all kinds of problems and challenges of the Yangtze River protection. While realizing the overall interests and collective rationality of the Yangtze River, the assessment result also satisfies the local interests and individual rationality of the administrative region in the basin.

This study focused on the Yangtze River Basin and used regional land use data as the main data source. These data were combined with other data to estimate the values of 10 ecosystem services within $1 \mathrm{~km}$ and $2 \mathrm{~km}$ from the Yangtze River and each of the upper, middle, and lower reaches of the river were analyzed. The ecosystem services value in 11 provincial-level regions and an in-depth analysis of the current ecological environment in the Yangtze River Basin are of great significance for guiding the ecological construction of the basin and achieving a 'win-win' for regional development and ecological protection. It was estimated that the ecological protection work in the Yangtze River Basin has impacted on the ecosystem services value of the basin ecosystem, providing a reference for the further protection of the Yangtze River and the healthy and efficient development of the Yangtze River Economic Belt.

\section{Materials and data}

\subsection{Research area}

The Yangtze River is the largest river in Asia. It is the third largest river in the world, and it is the longest river in China (Jin et al., 2018). The total water resource it contains amounts to 975.5 billion $\mathrm{m}^{3}$, accounting for $36 \%$ of the total river runoff in China. The Yangtze River is 20 times longer than the next longest river in China. It ranks as the world's third longest river after the Amazon River and the

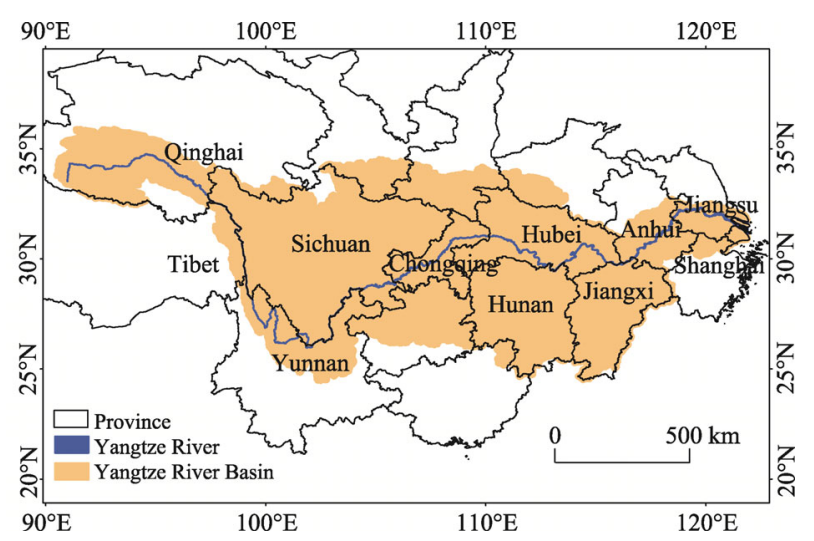

Figure 1 Location map of the Yangtze River Basin 
Congo River (Zaire River), which are both located in the equatorial rainforest. The Yangtze River originates from the Tanggula Mountains in Qinghai Province and eventually enters the East China Sea near Chongming Island in Shanghai. From west to east, the river traverses central China and crosses 11 provincial-level regions of Qinghai, Tibet, Sichuan, Yunnan, Chongqing, Hubei, Hunan, Jiangxi, Anhui, Jiangsu, and Shanghai. The drainage area covers 1.8 million $\mathrm{km}^{2}$, accounting for $20 \%$ of the total land area of China (Figure 1). Yichang, Hubei, and Hukou of Jiangxi Province are the boundaries of the upper, middle, and lower reaches of the Yangtze River, respectively. The upper reaches of the river in Yichang are the upstream area, the middle reaches are between Yichang and Hukou, and the lower reaches are below Hukou.

Because of its rich resources and numerous tributaries and lakes, as the Yangtze River traverses the southern area of China it provides important economic linkages for China's eastern and western regions. The Yangtze River Economic Belt covers 11 provinces and cities, including Shanghai, Jiangsu, Zhejiang, Anhui, Jiangxi, Hubei, Hunan, Chongqing, Sichuan, Yunnan, and Guizhou, with an area of approximately 2.05 million $\mathrm{km}^{2}$. The population and GDP account for more than $40 \%$ of the national total in China. The Yangtze River Economic Belt Strategy is a new round of reform and opening up and is important to the implementation of China's new regional open development strategy. It is a globally influential inland economic belt, a coordinated development zone for east-west interaction and cooperation, and an example of China opening to the outside world along the coast. It is also the first demonstration zone for the construction of an ecological civilization in China.

\subsection{Definition of research scope}

To promote the protection of the ecological environment of the Yangtze River Economic Belt, the Ministry of Environmental Protection, the Development and Reform Commission, and the Ministry of Water Resources jointly issued the Plan for the Protection of the Ecological Environment of the Yangtze River Economic Belt in July 2017. In the plan, it is clearly stated that new chemical industry facilities should be strictly prohibited within $1 \mathrm{~km}$ of the mainstream and its main tributaries, and that new petrochemical and coal chemical projects should be strictly controlled along the middle and upper reaches of the Yangtze River. To transfer highly polluting and high-emission enterprises from the downstream to upstream areas, industries that do not meet the requirements for shoreline locations, specific river and land sections, and an appropriate layout must withdraw unconditionally. Therefore, the study selected a 1-km region from the river as the core research area. The 'Conservation of the Yangtze River' strategy aims to shut down chemical companies within $15 \mathrm{~km}$ of the coast by 2025. The satellite remote sensing center of the Ministry of Environmental Protection of China interprets land use data within $2 \mathrm{~km}$ of the Yangtze River. Based on this background, after exploring the ecosystem services value in $1 \mathrm{~km}$ along the Yangtze River, the scope was expanded to $2 \mathrm{~km}$ from the river, to further explore the impact of the Yangtze River Conservation Project on the ecosystem services value, and provide a reference for future work.

\subsection{Data}

The number of land uses was determined from the 2017 high score of the Gaofen satellite 1 
(GF-1) and the resources satellite three (ZY-3) and was determined from cloudless or less cloudy (cloud coverage ratio $<1 \%$ ) remote sensing images. The spatial resolution of the remote sensing images was $8 \mathrm{~m}^{2} / \mathrm{m}$ and $6 \mathrm{~m}^{2} / \mathrm{m}$ for multispectral and full color images, respectively. This enabled the interpretation of land use types within $2 \mathrm{~km}$ of the Yangtze River. The net primary productivity (NPP) simulation data for the Yangtze River Basin in 2017 was obtained from the China National Earth System Science Data Sharing Platform (www. geodata.cn). The areas planted with rice, wheat, and corn, and the grain yield and unit area income and expenditure values were from 2017. The data were obtained from the China Statistical Yearbook and Compilation of Cost-Benefit Data of National Agricultural Products.

\section{Methods}

\subsection{Classification of ecosystem services}

In this study, ecosystem services were classified based on the methods of the Millennium Ecosystem Assessment (MA) (Meijer, 2008), which divides ecosystem services into supplying, regulating, and cultural services. In addition, referring to the work of Xie et al. (2008) on China's ecosystem services, water supply was added to the supply service category in response to the current water shortage situation in China. On this basis, the ecosystem services were further divided into 10 subcategories (Table 1).

Table 1 Classification of ecosystem services

\begin{tabular}{llll}
\hline Provisioning services & Regulating services & Supporting services & Cultural services \\
\hline Food production (FP) & Gas regulation (GR) & Soil retention (SR) & Aesthetic landscapes (AL) \\
Raw material production (RP) & Climate regulation (CR) & Species diversity (SD) & \\
Water supply (WS) & Environmental purification (EP) & \\
& Hydrological regulation (HR) & \\
\hline
\end{tabular}

\subsection{Correction of the ecosystem services value per unit area}

The basic equivalent of the ecosystem services value per unit area enables an assessment of the ecosystem services value in regional ecosystems. This value refers to the annual average value equivalent of various service functions per unit area for different types of ecosystems. Referring to the ecosystem services value calculated by Xie Gaodi (2010) (Table 2), this study revised the value of different ecosystem services in 2017 in terms of time and space.

In terms of space, this study used the ratio of the unit area grain yield of different provinces in the study area to the output of farmland grain area per unit area as the revised coefficient and revised the ecosystem services value per unit area to the ecosystem services value per unit area of the Yangtze River Basin. In terms of time, the service value per unit area of the Yangtze River Basin ecosystem was revised using the food production data per unit area in 2017. The corrected results are shown in Table 3.

Considering the close relationship between biomass and ecosystem services (Liu et al., 2018), based on the regional correction, this study used 2017 NPP data to modify the ecosystem services value of the Yangtze River Basin and compared the mean NPP value in the 2017 study area with the mean NPP of the ecosystem type to which the pixel belongs. The equivalent factor was adjusted as a functional coefficient. 
Table 2 Ecosystem service equivalent value per unit area (yuan/ha)

\begin{tabular}{|c|c|c|c|c|c|c|c|c|c|c|c|}
\hline \multicolumn{12}{|c|}{ Ecosystem service equivalent value per unit area } \\
\hline \multicolumn{2}{|c|}{ Ecosystem classification } & \multicolumn{3}{|c|}{$\begin{array}{c}\text { Provisioning } \\
\text { services }\end{array}$} & \multicolumn{4}{|c|}{ Regulating services } & \multicolumn{2}{|c|}{$\begin{array}{c}\text { Supporting } \\
\text { services }\end{array}$} & \multirow{2}{*}{$\begin{array}{c}\begin{array}{c}\text { Cultural } \\
\text { services }\end{array} \\
\mathrm{AL}\end{array}$} \\
\hline $\begin{array}{l}\text { Primary classi- } \\
\text { fication }\end{array}$ & $\begin{array}{l}\text { Secondary } \\
\text { classification }\end{array}$ & FP & $\mathrm{RP}$ & WS & GR & $\mathrm{CR}$ & EP & HR & SR & SD & \\
\hline \multirow[t]{2}{*}{ Farmland } & Dry land & 0.85 & 0.4 & 0.02 & 0.67 & 0.36 & 0.1 & 0.27 & 1.03 & 0.13 & 0.06 \\
\hline & Paddy field & 1.36 & 0.09 & -2.63 & 1.11 & 0.57 & 0.17 & 2.72 & 0.01 & 0.21 & 0.09 \\
\hline Forest & $\begin{array}{l}\text { Coniferous and } \\
\text { broad-leaved } \\
\text { mixed forest }\end{array}$ & 0.31 & 0.71 & 0.37 & 2.35 & 7.03 & 1.99 & 3.51 & 2.86 & 2.6 & 1.14 \\
\hline \multirow[t]{2}{*}{ Grassland } & Shrub & 0.19 & 0.43 & 0.22 & 1.41 & 4.23 & 1.28 & 3.35 & 1.72 & 1.57 & 0.69 \\
\hline & Shrubs & 0.38 & 0.56 & 0.31 & 1.97 & 5.21 & 1.72 & 3.82 & 2.4 & 2.18 & 0.96 \\
\hline Wetlands & Wetlands & 0.51 & 0.5 & 2.59 & 1.9 & 3.6 & 3.6 & 24.23 & 2.31 & 7.87 & 4.73 \\
\hline \multirow[t]{2}{*}{ Desert } & Desert & 0.01 & 0.03 & 0.02 & 0.11 & 0.1 & 0.31 & 0.21 & 0.13 & 0.12 & 0.05 \\
\hline & Bare land & 0 & 0 & 0 & 0.02 & 0 & 0.1 & 0.03 & 0.02 & 0.02 & 0.01 \\
\hline Waters & River system & 0.8 & 0.23 & 8.29 & 0.77 & 2.29 & 5.55 & 102.24 & 0.93 & 2.55 & 1.89 \\
\hline
\end{tabular}

Table 3 Correction of the ecosystem services value per unit area (yuan/ha) of the Yangtze River Basin

\begin{tabular}{cccccccccccc}
\hline $\begin{array}{c}\text { Equivalent } \\
\text { factor }\end{array}$ & China & Qinghai & Tibet & Sichuan & Yunnan & $\begin{array}{c}\text { Chong- } \\
\text { qing }\end{array}$ & Hubei & Hunan & Jiangxi & Anhui & Jiangsu \\
\hline 2010 & 481.19 & 359.49 & 518.53 & 487 & 346.53 & 498.41 & 550.65 & 572.8 & 519.6 & 450.43 & 592.64 \\
2017 & 532.66 & 349.69 & 540.32 & 525.41 & 419.84 & 504.3 & 562.41 & 593.69 & 561.09 & 506.25 & 633.41 \\
\hline
\end{tabular}

\subsection{Calculation of ecosystem service value}

After correcting the ecosystem services value per unit area, the value of the ecosystem service per unit area was obtained for different land use types by combining the basic equivalent factor tables of different types of ecosystems and the values of different types of ecosystem services. Then, based on the land use data of the study area, the total ecosystem services value of the study area was obtained. The calculation was as follows:

$$
E S V=\sum_{i=1}^{n} S_{\mathrm{i}} \times V C_{\mathrm{i}}
$$

where $E S V$ is the total ecosystem services value, $S_{i}$ is the area of the $i$-type of land use in the study area, $V C_{i}$ is the ecosystem services value per unit area of the $i$-type of land use, and $i$ is the land use type.

\section{Results and analysis}

\subsection{The ecosystem services value}

The ecosystem services value within $1 \mathrm{~km}$ and $2 \mathrm{~km}$ from the Yangtze River in 2017 was estimated using the revised ecosystem services value equivalent factors and the area of different land use types in the Yangtze River Basin. The study was conducted based on the upper, middle, and lower reaches of the river (Figure 2). The total ecosystem services value within $1 \mathrm{~km}$ and $2 \mathrm{~km}$ was estimated to be 37.208 and 43.769 billion yuan, respectively. The 
total ecosystem services value within the $2 \mathrm{~km}$ was 1.27 times greater than the value within $1 \mathrm{~km}$. Within $2 \mathrm{~km}$, the ecosystem services value was the highest in the middle reaches, accounting for 12.903 billion yuan or $35 \%$ of the total ecosystem services value. In the upper reaches, the value was 12.455 billion yuan, accounting for $33 \%$ of the total ecosystem services value. In the lower reaches, the ecosystem services value was the low-

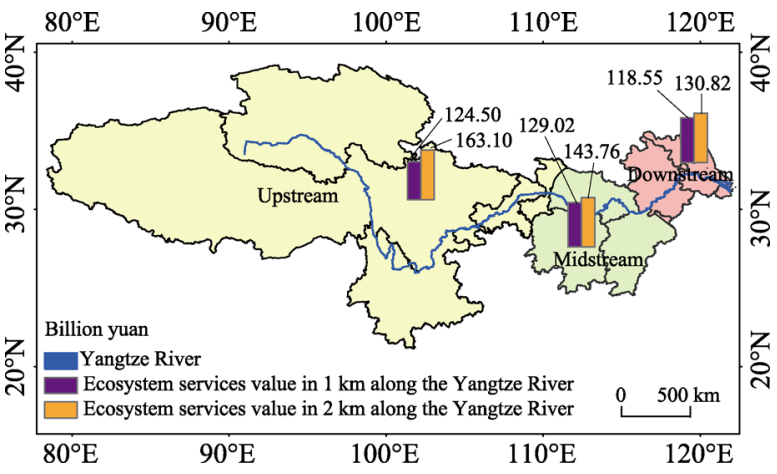

Figure 2 Ecosystem services value along the upper, middle and lower reaches of the Yangtze River in 2017 est, accounting for only 11.555 billion yuan. Within $1 \mathrm{~km}$, the ecosystem services value was the highest in the upper reaches, accounting for 16.31 billion yuan or $37 \%$ of the total ecosystem services value. In the middle reaches, the value was 14.376 billion yuan, accounting for $33 \%$ of the total ecosystem services value. In the lower reaches, the ecosystem services value was the lowest, accounting for 13.083 billion yuan or $30 \%$ of the total ecosystem services value.

To understand the ecological environment of the Yangtze River Basin, the value of 10 different ecosystem services in the Yangtze River Basin in 2017 was estimated (Table 4). Regulating services were the dominant service over the whole Yangtze River Basin, accounting for $81.6 \%(78.9 \%), 78.9 \%(87.0 \%)$, and $87.3 \%(87.3 \%)$ of the ecosystem services value in the upper, middle, and lower reaches of the Yangtze River in $1 \mathrm{~km}(2 \mathrm{~km})$, respectively. The contribution of supporting and cultural services to the upper, middle, and lower reaches of the Yangtze River differed. In the upper reaches of the Yangtze River, in addition to the regulating services, the order was as follows: supporting services $>$ provisioning services $>$ cultural services. However, in the middle and lower reaches of the Yangtze River, in addition to regulating services, the order was as follows: provisioning services $>$ supporting services $>$ cultural services.

Table 4 Value of different ecosystem services in the Yangtze River Basin in 2017 (billion yuan)

\begin{tabular}{lccccccc}
\hline & Region & \multicolumn{2}{c}{ Upper reaches } & \multicolumn{2}{c}{ Middle reaches } & \multicolumn{2}{c}{ Lower reaches } \\
\cline { 3 - 8 } & & $1 \mathrm{~km}$ & $2 \mathrm{~km}$ & $1 \mathrm{~km}$ & $2 \mathrm{~km}$ & \multicolumn{1}{c}{$1 \mathrm{~km}$} & $2 \mathrm{~km}$ \\
\hline Provision- & FP & 1.83 & 3.05 & 1.76 & 2.69 & 1.35 & 2.00 \\
ing services & RP & 1.35 & 2.41 & 0.53 & 0.76 & 0.38 & 0.51 \\
& WS & 4.92 & 4.42 & 6.25 & 5.26 & 6.43 & 5.97 \\
Regulating & GR & 4.94 & 8.87 & 2.29 & 3.53 & 1.62 & 2.35 \\
services & CR & 12.84 & 22.85 & 4.90 & 6.93 & 3.49 & 4.46 \\
& EP & 7.17 & 10.29 & 6.12 & 7.03 & 5.52 & 6.19 \\
& HR & 76.70 & 86.75 & 99.26 & 107.53 & 92.84 & 101.17 \\
Supporting & SR & 5.36 & 9.49 & 1.92 & 2.65 & 1.43 & 1.78 \\
services & SD & 6.15 & 10.02 & 3.65 & 4.57 & 3.29 & 3.87 \\
Cultural & AL & 3.23 & 4.96 & 2.36 & 2.82 & 2.21 & 2.54 \\
services & & & & & & & \\
\hline
\end{tabular}


Among the 10 ecosystem services, hydrological regulation contributed the most to the ecosystem services value, and raw material production contributed the least. Hydrological regulation accounted for $75.5 \%(67.4 \%), 88.2 \%(86.0 \%)$, and $89.7 \%(88.6 \%)$ in the upper, middle, and lower reaches of the Yangtze River in $1 \mathrm{~km}(2 \mathrm{~km})$, respectively, while gas regulation accounted for $4.9 \%(6.9 \%), 2.8 \%(2.6 \%)$, and $1.6 \%(2.1 \%)$ in the upper, middle, and lower reaches, respectively. Among the provisioning services, water resources accounted for the largest proportion, accounting for $60.7 \%(44.7 \%), 73.2 \%(60.4 \%)$, and $78.8 \%(70.5 \%)$ in the upper, middle, and lower reaches of the Yangtze River in $1 \mathrm{~km}(2 \mathrm{~km})$, respectively, while raw material production accounted for the smallest proportion, accounting for $16.7 \%(24.4 \%), 6.2 \%(8.7 \%)$, and $4.7 \%(6.0 \%)$ in the upper, middle, and lower reaches, respectively. Among the supporting services, species diversity accounted for $46.6 \%$ (48.6\%), 34.5\% (36.7\%), and 30.3\% (31.5\%) in the upper, middle, and lower reaches of the Yangtze River in $1 \mathrm{~km}(2 \mathrm{~km})$, respectively, while soil retention in the upper, middle, and lower reaches accounted for 53.4\% (51.4\%), 65.5\% (63.3\%), and 69.7\% (68.5\%), respectively.

\subsection{Ecosystem services values in each province}

The ecological service values in the provinces along the Yangtze River in 2017 were estimated (Tables 5 and 6). In $1 \mathrm{~km}(2 \mathrm{~km})$ along the Yangtze River, the highest ecosystem services value was in Hubei Province, accounting for approximately 100.22 (111.99) billion yuan, which was $26.9 \%$ (25.6\%) of the ecosystem services value of the whole Yangtze River Basin. Jiangsu, Chongqing, and Anhui provinces also had high values of 62.42 (66.97), $51.80(60.70)$, and 52.78 (58.17) billion yuan, respectively, accounting for $16.8 \%(15.3 \%)$, $13.9 \%(13.9 \%)$, and $14.2 \%(13.3 \%)$ of the total ecosystem services value of the basin. In $1 \mathrm{~km}(2 \mathrm{~km})$ along the Yangtze River, the lowest ecosystem services values were in Tibet Autonomous Region and Shanghai Municipality, at 311 (522) and 334 (568) million yuan, respectively, accounting for $0.83 \%(1.19 \%)$ and $0.90 \%(1.30 \%)$ of the total ecosystem services value of the basin (Figure 3).

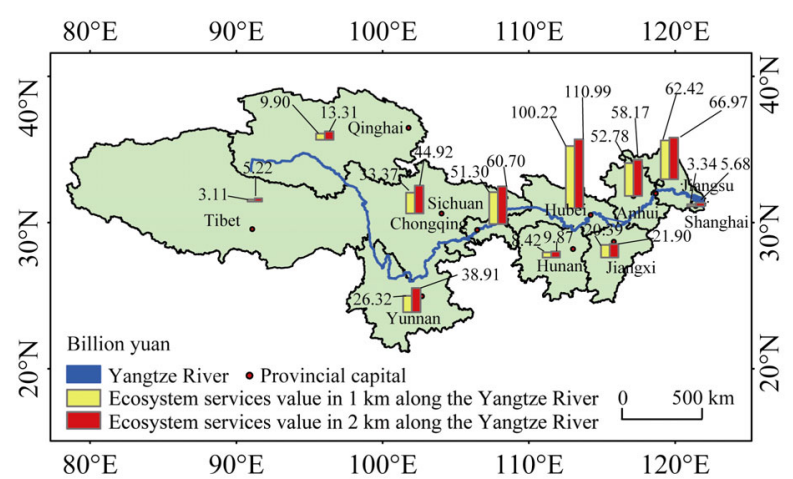

Figure 3 Ecosystem services values in the provincial-level regions along the Yangtze River in 2017

In the provinces with a high total ecosystem services value, there were differences in the contributions of ecosystem services in $1 \mathrm{~km}$ and $2 \mathrm{~km}$ along the Yangtze River. In $1 \mathrm{~km}$ in Hubei Province, hydrological regulation and water supply were the most important ecosystem services, while hydrological regulation and climate regulation were more important in 2 $\mathrm{km}$. Hydrological regulation and water supply were the most important ecosystem services in $1 \mathrm{~km}$ along the Yangtze River in Anhui Province, while in $2 \mathrm{~km}$, hydrological regulation and environmental purification were more important. The types of ecosystem services that contributed most to the overall value in $1 \mathrm{~km}$ and $2 \mathrm{~km}$ along the Yangtze River in Chongqing and Jiangsu were the same. 
Table 5 Ecosystem services value of provinces in $1 \mathrm{~km}$ along the Yangtze River in 2017 (billion yuan)

\begin{tabular}{|c|c|c|c|c|c|c|c|c|c|c|}
\hline \multirow{2}{*}{ Province } & \multicolumn{3}{|c|}{ Provisioning services } & \multicolumn{4}{|c|}{ Regulating services } & \multicolumn{2}{|c|}{ Supporting services } & \multirow{2}{*}{$\begin{array}{c}\begin{array}{c}\text { Cultural } \\
\text { services }\end{array} \\
\text { AL }\end{array}$} \\
\hline & FP & $\mathrm{RP}$ & WS & GR & $\mathrm{CR}$ & EP & HR & SR & $\mathrm{SD}$ & \\
\hline Qinghai & 0.0888 & 0.0865 & 0.5345 & 0.2902 & 0.8274 & 0.5401 & 6.5251 & 0.3537 & 0.4219 & 0.2317 \\
\hline Tibet & 0.0497 & 0.0696 & 0.0951 & 0.2322 & 0.6378 & 0.2315 & 1.1288 & 0.2845 & 0.2641 & 0.1217 \\
\hline Sichuan & 0.5278 & 0.4126 & 1.2240 & 1.4929 & 3.8585 & 1.9934 & 19.4919 & 1.6417 & 1.8025 & 0.9243 \\
\hline Yunnan & 0.4623 & 0.4130 & 0.7399 & 1.4977 & 3.9535 & 1.7036 & 13.3708 & 1.6477 & 1.7023 & 0.8297 \\
\hline Chongqing & 0.7058 & 0.3711 & 2.3247 & 1.4290 & 3.5615 & 2.6985 & 36.1861 & 1.4362 & 1.9590 & 1.1249 \\
\hline Hubei & 1.2793 & 0.4184 & 5.0206 & 1.7553 & 3.9179 & 4.7731 & 76.7507 & 1.5561 & 2.8869 & 1.8580 \\
\hline Hunan & 0.1489 & 0.0312 & 0.3402 & 0.1603 & 0.2808 & 0.3909 & 6.5989 & 0.1029 & 0.2228 & 0.1475 \\
\hline Jiangxi & 0.3294 & 0.0763 & 0.8858 & 0.3731 & 0.6996 & 0.9517 & 15.9076 & 0.2617 & 0.5429 & 0.3579 \\
\hline Anhui & 0.6930 & 0.1949 & 2.6488 & 0.8452 & 1.7636 & 2.4713 & 41.0256 & 0.7056 & 1.4649 & 0.9679 \\
\hline Jiangsu & 0.5792 & 0.1668 & 3.6851 & 0.6678 & 1.5509 & 2.8647 & 49.5145 & 0.6443 & 1.6248 & 1.1231 \\
\hline Shanghai & 0.0743 & 0.0214 & 0.0947 & 0.1034 & 0.1728 & 0.1803 & 2.3006 & 0.0784 & 0.1977 & 0.1202 \\
\hline Total & 4.9383 & 2.2616 & 17.5933 & 8.8472 & 21.2243 & 18.7990 & 268.8007 & 8.7127 & 13.0897 & 7.8070 \\
\hline
\end{tabular}

See Table 1 for the definition of ecosystem services.

Table 6 Ecosystem services value of provinces in the $2 \mathrm{~km}$ along the Yangtze River in 2017 (billion yuan)

\begin{tabular}{ccccccccccc}
\hline \multirow{2}{*}{ Province } & \multicolumn{2}{c}{ Provisioning services } & \multicolumn{3}{c}{ Regulating services } & & Supporting services & $\begin{array}{c}\text { Cultural } \\
\text { services }\end{array}$ \\
\cline { 2 - 12 } & FP & RP & WS & GR & CR & EP & HR & SR & SD & AL \\
\hline Qinghai & 0.1360 & 0.1658 & 0.6309 & 0.5587 & 1.5916 & 0.8025 & 7.6446 & 0.6807 & 0.7299 & 0.3721 \\
Tibet & 0.0921 & 0.1356 & 0.1295 & 0.4485 & 1.2359 & 0.4127 & 1.4988 & 0.5502 & 0.4970 & 0.2242 \\
Sichuan & 0.9252 & 0.7399 & 1.0231 & 2.7135 & 6.9125 & 2.9420 & 22.3420 & 2.9174 & 2.9888 & 1.4504 \\
Yunnan & 0.7629 & 0.7825 & 0.7285 & 2.8046 & 7.5283 & 2.7674 & 15.9221 & 3.1201 & 3.0620 & 1.4293 \\
Chongqing & 1.1381 & 0.5844 & 1.9039 & 2.3408 & 5.5787 & 3.3670 & 39.3446 & 2.2183 & 2.7440 & 1.4803 \\
Hubei & 2.0489 & 0.6096 & 4.1675 & 2.7886 & 5.5997 & 5.5100 & 83.2283 & 2.1601 & 3.6448 & 2.2321 \\
Hunan & 0.2524 & 0.0452 & 0.2274 & 0.2627 & 0.3933 & 0.4650 & 7.6276 & 0.1352 & 0.2814 & 0.1797 \\
Jiangxi & 0.3853 & 0.1015 & 0.8639 & 0.4829 & 0.9351 & 1.0541 & 16.6703 & 0.3547 & 0.6477 & 0.4092 \\
Anhui & 1.0070 & 0.2531 & 2.3904 & 1.1915 & 2.2195 & 2.7624 & 44.6651 & 0.8684 & 1.7111 & 1.1021 \\
Jiangsu & 0.8026 & 0.2086 & 3.5493 & 0.9202 & 1.8903 & 3.1166 & 52.6429 & 0.7676 & 1.8346 & 1.2410 \\
Shanghai & 0.1869 & 0.0442 & 0.0316 & 0.2337 & 0.3500 & 0.3094 & 3.8588 & 0.1471 & 0.3275 & 0.1942 \\
Total & 7.7373 & 3.6705 & 15.6460 & 14.746 & 34.2348 & 23.5090 & 295.4449 & 13.9198 & 18.4686 & 10.3145 \\
\hline
\end{tabular}

See Table 1 for the definition of ecosystem services

The total ecosystem services value in each province and city was used to evaluate the regional ecosystem services value, and the ecosystem services value per unit area was used to compare the values of the regional ecological environments. By calculating the ecosystem services per unit area of the Yangtze River Basin in 2017, it was found that the ecosystem services value of $1 \mathrm{~km}(2 \mathrm{~km})$ along the Yangtze River was the highest in Hubei Province at 1707.12 (16.6641) million yuan/ha, while the second highest was Jiangsu Province at 123.108 (11.5558) million yuan/ha. The ecosystem services value of $1 \mathrm{~km}$ in Chongqing was lower than that in Anhui Province, but the values in the $2 \mathrm{~km}$ displayed a different pattern, with the ecosystem services value being lower in the province. The ecosystem services value 
per unit area in $1 \mathrm{~km}(2 \mathrm{~km})$ along the Yangtze River in Tibet and Shanghai was low, with Tibet accounting for 8239 (11680) million yuan/ha, followed by Shanghai at 8818 (1264) million yuan/ha. The ecosystem services value per unit area in Hubei Province was approximately 20.72 (14.27) times that of Tibet (Figure 4).

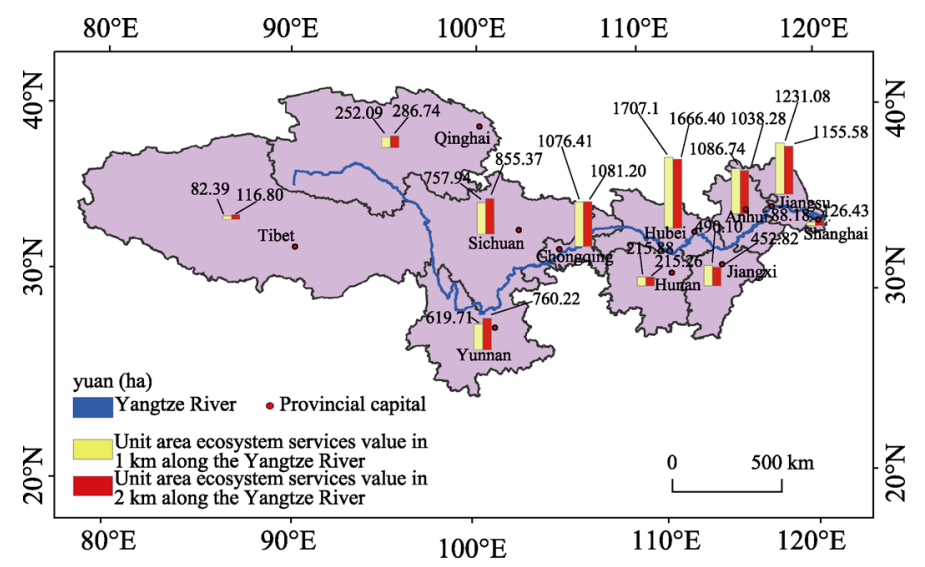

Figure 4 Unit area ecosystem services value along the Yangtze River in 2017

\section{Discussion}

\subsection{Ecosystem services value in the Yangtze River Basin}

Within $1 \mathrm{~km}$ and $2 \mathrm{~km}$ along the Yangtze River, the ecosystem services value of the lower reaches was lower than that of the middle and upper reaches, mainly because the vegetation coverage of the upper and middle reaches was better than that of the lower reaches, and the average NPP in the upper and middle reaches was larger than in the lower reaches. In $1 \mathrm{~km}$, the forest cover in the upper reaches was higher than in the middle reaches, and the cultivated land area in the middle reaches was equal to that in the middle reaches. However, the equivalent factor in the middle reaches was 1.22 times that in the lower reaches, and the NPP of vegetation in the middle reaches was higher than in the upper reaches, causing the ecosystem services value in the middle reaches to be higher than in the upper reaches. In the $2 \mathrm{~km}$, the forestland area in the upper reaches accounted for $65 \%$ of the total area. Forestland was the main land use type, while forest cover in the middle reaches accounted for $19 \%$ of the total area. Cultivated land was the main land use type. Forest cover in the upper reaches was 9.85 times higher than in the middle reaches. The ecosystem services value in a unit area of forestland was higher than for other land uses, which increased the ecosystem services value in the upper reaches.

The differences in the ecosystem services value in the upper, middle, and lower reaches of the Yangtze River were mainly related to the land use pattern. Within $1 \mathrm{~km}$, the proportion of forest and grassland in the upper and middle reaches of the Yangtze River was larger than that in the lower reaches of the Yangtze River. In the $2 \mathrm{~km}$, the proportion of forest and grassland area in the upper reaches increased significantly, while the proportions of cultivated and bare land in the middle and lower reaches were larger. There were many areas of forest and grassland in the upper reaches of the river basin, and these ecosystems contained a 
large amount of biomass and had excellent ecological resources, resulting in a relatively high ecosystem services value in the region. The middle and lower reaches of the river basin were dominated by cultivated and bare land. The human activity in bare land areas interfered with the functioning of the ecosystems; thus, the ecosystem services value was lower than in the upper reaches.

Hydrological regulation (a regulating service) was the dominant service in the upper, middle, and lower reaches of the Yangtze River because the Yangtze River and its tributaries had enormous water resources and there were a large number of important wetlands along the river, which play an important role in regulating the hydrological functioning of the whole region. In addition to regulating services, the upstream area provided more supporting services than provisioning services, while the downstream and middle reaches provided more provisioning services than supporting services. In the upstream area forest cover was higher, human activities had less impact on the regional ecological environment, and the regional function of species protection in the aquatic germplasm resources reserve was stronger. Farmland and bare land accounted for a large proportion of the land area in the middle and lower reaches, and there was a relatively high level of human activity. Provisioning services provide the material basis of production and life for local residents. The food and raw material supplies are crucial for the livelihoods of local residents and have direct economic benefits for the region.

\subsection{Ecosystem services value in the provinces}

Among all land use types, the ecosystem services value of the river system was the highest, followed by that of wetland and coniferous-broad-leaved mixed forest. Among the provinces and cities within the Yangtze River Basin, Hubei Province had the largest water areas in 1 $\mathrm{km}$ and $2 \mathrm{~km}$ along the Yangtze River at 13.3498 and 14.1116 ha. The ecosystem services value of the river system was much higher than that of other land types, making the total ecosystem value of Hubei Province higher than that of other provinces and cities. Among the provinces and municipalities along the Yangtze River, Jiangsu Province had the largest area of wetland and the second largest area of water; thus, the total ecosystem services value was the highest in Jiangsu Province. The total ecosystem services value in Tibet and Shanghai was relatively low, mainly due to the low ecosystem services value of the main land use types in the region.

In the estimation of ecosystem services value per unit area, Hubei Province had the highest value in terms of its cities along the Yangtze River. There are abundant water resources in Hubei Province. The water supply and hydrological regulation of the water system have a high value in terms of the regional ecological environment. Wetlands play an important role in the protection of regional biodiversity, regulation of runoff and climate, and can also improve water quality. Wetlands will enhance water supply, provide hydrological regulation, and improve biodiversity. Jiangsu Province has a large water and wetland area; thus, the province had a better regional ecological environment than the other provinces that the Yangtze River flows through. In $1 \mathrm{~km}$ and $2 \mathrm{~km}$ along the Yangtze River in Tibet, there was little vegetation cover and relatively low biodiversity, which resulted in a low regional environmental carrying capacity and fragile ecological environment. The regional water re- 
sources are limited and hydrological regulation is poor. There are many different ecological and environmental problems in the region, such as grassland degradation, land desertification, and soil erosion. As a national mega city, Shanghai has experienced rapid economic development, with an increase in both the area of built-up land and population. Limitations in the ecological carrying capacity have become increasingly prominent in the region, which has resulted in the low ecosystem services value per unit area.

\subsection{The impact of ecological protection measures on the environment}

On January 5, 2016, President Xi highlighted the development of the Yangtze River Economic Belt in Chongqing. The promotion of the development of the Yangtze River Economic Belt must adhere to the strategic orientation of prioritizing the ecological environment and green development, and the current and future processes will be maintained over the long term. Restoring the Yangtze River ecological environment is an enormous task, with the area in need of a large amount of protection rather than development. Based on the current problems of increased ecosystem fragmentation, over-exploitation of natural shorelines, and extensive use of environmental resources in the Yangtze River Basin, the relevant departments of the state have formulated policies for improving the ecological environment, developing the economic transformation process, and reforming the economic system and its mechanisms. At the same time, the local governments of provinces and cities along the Yangtze River are encouraged to implement measures to protect the ecological environment in the region's peripheral to the coastline, to create a red line for the protection of ecological areas and other environmentally sensitive areas. The discharge of domestic wastewater from villages along the Yangtze River is an important factor affecting the ecological environment of the Yangtze River. Through field investigations, it was found that in addition to the 'reconstruction and transformation' of chemical enterprises within $1 \mathrm{~km}$ along the Yangtze River, some provinces and cities have also increased their water protection measures. The demolition and relocation of villages within $1 \mathrm{~km}$ of the river and the comprehensive regreening of shorelines would enable a quantitative prediction of the improvement in ecosystem services value, with the demolition area reclaimed for planting shrubs. The results showed that the total ecosystem services value in the Yangtze River Basin was 37.207 billion yuan in $1 \mathrm{~km}$ along the Yangtze River in 2017. After the relocation of villages, the total ecosystem services value was estimated to be 37.734 billion yuan, i.e., the total value of regional ecosystem services would increase by 527 million yuan. In $2 \mathrm{~km}$ along the Yangtze River, the total ecosystem services value was 437 million yuan in 2017. After the relocation of villages, the total ecosystem services value was estimated to be 44.744 billion yuan, representing an increase of 975 million yuan in the total ecosystem services value (Figure 5).

\subsection{Proposal}

To ensure the management of the ecological environment of the Yangtze River, it is necessary to clarify the problems involved in the overall protection of the basin, including the interconnections of water and ecological problems, the conflicts between development and protection in key areas, and the prioritization of the ecological and environmental functions of the Yangtze River Economic Belt. We need new methods of green development. In terms 


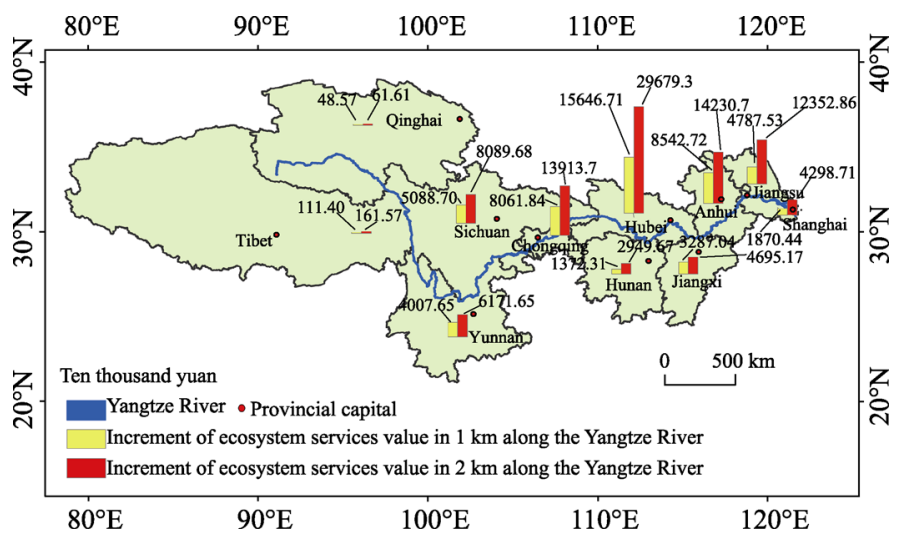

Figure 5 Increment of ecosystem services value along the Yangtze River in 2017

of governance, there is a need to co-ordinate the overall protection, system rehabilitation, and comprehensive management of the upper, middle, and lower reaches of the river. High-intensity hydropower development and resource development in the upper reaches of the basin have caused great ecological damage and have directly affected the ecological environment in the middle and lower reaches. Therefore, in upstream management, prevention and protection should be the main priorities, and hydropower development should be strictly controlled and restricted to downstream areas. The space for development should consider the protection and restoration of the environment, controlling the releases of water resources in the middle and upper reaches of the basin, and ensuring an adequate water flow for ecological purposes during the dry season. There is also a need to actively respond to the intrusion of salt-water from the sea, the shrinkage of the wetlands in the middle reaches, and the degradation of rivers and lakes. Other problems include the overloading of resources and the environment, and large amounts of discharged pollutants. Therefore, in downstream management, ecological recovery should be the main focus.

\section{Conclusions}

This study used Costanza's method of estimating the ecosystem services value, and revised Xie Gaodi's “Equivalent ecosystem services value per unit area of China's ecosystem" using the value of farmland production services and NPP. Ten different ecosystem services were analyzed in $1 \mathrm{~km}$ and $2 \mathrm{~km}$ from the Yangtze River in 2017, and the ecosystem services value in the upper, middle, and lower reaches of the Yangtze River Basin was estimated. The ecosystem services value of 11 provinces and cities along the Yangtze River was determined and the analysis was repeated for areas in $1 \mathrm{~km}$ and $2 \mathrm{~km}$ under conditions where the existing villages were relocated. The results showed the following:

(1) The total ecosystem services value along the Yangtze River in $1 \mathrm{~km}$ was 37.208 billion yuan. The total ecosystem services value in the middle reaches $>$ the total ecosystem services value in the upper reaches $>$ the total ecosystem services value in the lower reaches. The total ecosystem services value in $2 \mathrm{~km}$ was 43.769 billion yuan, and the total ecosystem services value in the upper reaches $>$ the total ecosystem services value in the middle reaches $>$ the ecosystem services value in the lower reaches.

(2) Within the whole Yangtze River Basin, regulating services accounted for $81.6 \%$ $(78.9 \%)$ of the ecosystem services value in $1 \mathrm{~km}(2 \mathrm{~km})$ along the Yangtze River. The con- 
tributions of provisioning, supporting, and cultural services to the ecosystem services value in the upper, middle, and lower reaches of the Yangtze River were different. In addition to the regulating services, the order was as follows: supporting services $>$ provisioning services $>$ cultural services in the upper reaches of the Yangtze River. In the middle and lower reaches of the Yangtze River, in addition to the regulating services, the order was as follows: provisioning services $>$ supporting services $>$ cultural services. Among the 10 ecosystem services, hydrological regulation made the largest contribution to the ecosystem services value, while raw material production contributed the least.

(3) In $1 \mathrm{~km}(2 \mathrm{~km})$ along the Yangtze River, the highest ecosystem services value was estimated in Hubei Province, which accounted for approximately 10.222 (111.99) billion yuan or $26.9 \%(25.6 \%)$ of the total ecosystem services value in the Yangtze River Basin. The lowest ecosystem services values were estimated in Tibet and Shanghai, with values of 311 (522) and 334 (568) million yuan, respectively. The differences in total ecosystem services value among provinces were related to land use types.

(4) In $1 \mathrm{~km}$ along the Yangtze River, the total ecological value of the region was estimated to increase by 527 million yuan after the relocation of villages. In $2 \mathrm{~km}$ along the Yangtze River, the total ecological value of the region was estimated to increase by 975 million yuan after the relocation of villages.

\section{References}

Anselin L, 1995. Local indicators of spatial association: LISA. Geographical Analysis, 27(2): $93-115$.

Berta M L, Erik G B, Marina G L et al., 2014. Trade-offs across value-domains in ecosystem services assessment. Ecological Indicators, 37(A): 220-228.

Bolliger J, Bttig M, Gallati J et al., 2011. Landscape multifunctionality: A powerful concept to identify effects of environmental change. Regional Environment Change, 11: 203-206.

Chen W, Li J, Zhu L, 2019. Spatial heterogeneity and sensitivity analysis of ecosystem services value in the Middle Yangtze River region. Journal of Natural Resources, 34(2): 325-337. (in Chinese)

Cheng J, Cheng J, Wu J et al., 2017. Changes of land use and ecosystem service functions in Yangtze River Basin from 2000-2010. Resources and Environment in the Yangtze Basin, 26(6): 894-901. (in Chinese)

Costanza R, Ralph d'Arge, Rudolf G et al., 1997. The value of the world's ecosystem services and natural capital. World Environment, 387(1): 3-15.

Daily G C, Polasky S, Goldstein J et al., 2009. Ecosystem services in decision making: time to deliver. Frontiers in Ecology \& the Environment, 7(1): 21-28.

Fisher B, Turner R K, 2008. Ecosystem services: Classification for valuation. Biological Conservation, 141(5): 1167-1169.

Fu B, 2010. Trends and priority areas in ecosystem research of China. Geographical Research, 29(3): 383-396. (in Chinese)

$\mathrm{Fu} \mathrm{B}, \mathrm{Yu} \mathrm{D}, \mathrm{Lv} \mathrm{N}, 2017$. Indicator systems and methods for evaluating biodiversity and ecosystem services. Acta Ecologica Sinica, 37(2): 341-348. (in Chinese)

Huang C, Yang J, Zhang W, 2013. Development of ecosystem services evaluation models: Research progress. Chinese Journal of Ecology, 32(12): 3360-3367. (in Chinese)

$\mathrm{Xu}$ H, Newton A, Wolanski E et al., 2015. The fate of phosphorus in the Yangtze (Changjiang) Estuary, China, under multi-stressors: Hindsight and forecast. Estuarine, Coastal and Shelf Science, 20(9): 1-6.

Jin G, Chen K, Wang P et al., 2019. Trade-offs in land-use competition and sustainable land development in the North China Plain. Technological Forecasting and Social Change, 141: 36-46.

Jin G, Deng X Z, Zhao X D et al., 2018. Spatiotemporal patterns in urbanization efficiency within the Yangtze 
River Economic Belt between 2005 and 2014. Journal of Geographical Sciences, 28(8): 1113-1126.

Jin G, Li Z H, Deng X Z et al., 2019. An analysis of spatiotemporal patterns in Chinese agricultural productivity between 2004 and 2014. Ecological Indicators, 105: 591-600.

Kreuter U, Hrris H, Malock M et al., 2001. Change in ecosystem service values in the San Antonio area, Texas. Ecological Economics, 39(3): 333-346.

Li S C, Bing Z L, Jin G, 2019. Spatially explicit mapping of soil conservation service in monetary units due to land use/cover change for the Three Gorges Reservoir Area, China. Remote Sensing, 11(4): 468.

Liu H, Wu J, Chen X, 2018. Study on spatial-temporal change and trade-off/synergy relationships of ecosystem services in the Danjiangkou water area. Acta Ecologica Sinica, 38(13): 4609-4624. (in Chinese)

Liu Y, Long H, 2017. Study on the spatiotemporal patterns of land use transition and its impact on ecological service function of the middle of Yangtze River Economic Belt. Economic Geography, 37(11): 161-170. (in Chinese)

Meijer K, 2008. Ecosystems and human well-being: Our human planet: Summary for decision makers (Millennium Ecosystem Assessment Series). Journal of Chromatography A, 1180(1/2): 66-72.

Millennium Ecosystem Assessment (MEA), 2005. Ecosystems and human well-being: Biodiversity synthesis. Washington DC: World Resources Institute.

National Bureau of Statistics of the People's Republic of China, 2010. Chinese Statistical Yearbook. Beijing: China Statistics Press.

National Bureau of Statistics of the People's Republic of China, 2017. China Statistical Yearbook. Beijing: China Statistics Press.

Nieto-Romero M, Oteros-Rozas E, González, José A et al., 2014. Exploring the knowledge landscape of ecosystem services assessments in Mediterranean agroecosystems: Insights for future research. Environmental Science \& Policy, 37(3): 121-133.

Ouyang Z, Wang X, Miao H, 1999. A primary study on Chinese terrestrial ecosystem services and their ecological-economic values. Acta Ecologica Sinica, 19(5): 607-613. (in Chinese)

Priess J, Minler M, Klein A, 2007. Linking deforestation scenarios to pollination services and economic return in coffee agroforestry systems. Ecological Applications, 17: 407-417.

Raudsepp-Hearne C, Peterson G D, Mooney B H A, 2010. Ecosystem service bundles for analyzing tradeoffs in diverse landscapes. Proceedings of the National Academy of Sciences of the United States of America, 107(11): 5242-5247.

The Price Department of the State Development and Reform Commission of China, 2011. National Agricultural Products Cost Return Assembly. Beijing: China Statistics Press.

Wang L, He Q, 2015. A review of the ecosystem value based on emergy theory. Ecological Economy, 31(4): 133-136. (in Chinese)

Wiens J, 2009. Landscape ecology as a foundation for sustainable conservation. Landscape Ecology, 24: $105-1065$.

Wilson C L, Matthews W H, 1970. Mans impact on the global environment: Assessment and recommendations for action. Report of the Study of Critical Environment Problems (SCEP) 1970. Cambridge, Massachusetts: MIT Press, 319.

Xie G, Zhang C, Zhang L et al., 2015. Improvement of the evaluation method for ecosystem service value based on per unit area. Journal of Natural Resources, 30(8): 1243-1254. (in Chinese)

Xie G, Zhen L, Lu C et al., 2008. Expert knowledge based valuation method of ecosystem services in China. Journal of Natural Resources, 23(5): 911-919. (in Chinese)

Yang R J, Wang L J, Liu W L et al., 2019. Design and progress of joint research on ecological environment protection and restoration of the Yangtze River. Environment and Sustainable Development, 44(5): 37-42. (in Chinese)

Yang S, Hu S, Qu S, 2018. Spatial dynamics of ecosystem service value in middle Yangtze River Economic Region from 1990 to 2014. Research of Soil and Water Conservation, 25(3): 164-169. (in Chinese) 